\title{
SEMIWORKS EVALUATION OF THE MANGANESE DIOXIDE HEAD-END STEP IN THE THOREX PROCESS
}

A. A. Kishbaugh
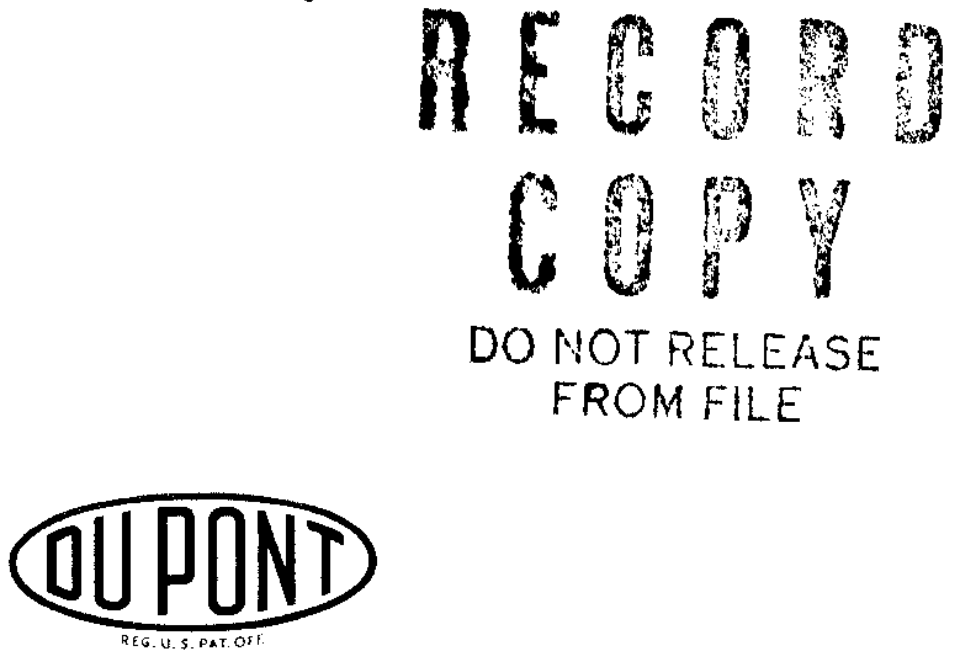

ISSUED BY

Savannah River Laboratory

Aiken, South Carolina 


\section{LEGAL NOTICE}

This report was prepared as an account of Government sponsored work. Neither the United States, nor the Commission, nor any person acting on behalf of the Commission:

A. Makes any warranty or representation, expressed or implied, with respect to the accuracy, completeness, or usefulness of the information contained in this report, or that the use of any information, apparatus, method, or process disclosed in this report may not infringe privately owned rights; or

B. Assumes any liabilities with respect to the use of, or for damages resulting from the use of any information, apparatus, method, or process disclosed in this report.

As used in the above, "person acting on behalf of the Commission" includes any employee or contractor of the Commission, or employee of such contractor, to the extent that such employee or contractor of the Commission, or employee of such contractor prepares, disseminates, or provides access to, any information pursuant to his employment or contract with the Commission, or his employment with such contractor.

Printed in USA. Price $\$ 1.00$

Avaliable from the Clearinghouse for Federal scientific and Technical Information, National Bureau of Standards, U. S. Department of Commerce, Springfield, Virginia 
$D P-982$

Chemical Separation Processes for Plutonium and Uranium (TID-4500, 43rd Ea.)

\section{SEMIWORKS EVALUATION OF THE MANGANESE \\ DIOXIDE HEAD-END STEP IN THE THOREX PROCESS}

by

Albert A. Kishbaugh

Approved by

D. S. Webster, Research Manager Separations Englneering Division

July 1965

E. I. DU PONT DE NEMOURS \& COMPANY SAVANNAH RIVER LABORATORY AIKEN, SOUTH CAROLINA CONTRACT AT(07.2)-1 WITH THE UNITED STATES ATOMIC ENERGY COMMISSION 


\begin{abstract}
The standard Savannah Rlver Plant procedure for precipitating $\mathrm{MnO}_{2}$ as a head-end step in the Purex process is satisfactory for sorption of protactinium in the dilute Thorex process at rates of $\sim 4000 \mathrm{lb}$ $\mathrm{Th} /$ day with the following modifications: (1) sulfamic acld 1 s added to the dissolver solution to decompose nitrous acid, which would otherwise dissolve some of the $\mathrm{MnO}_{2}$, (2) residual liquid skimmed from the centrifuge is recycled, and (3) the volume of dilute acid used in each of the flve washes of the $\mathrm{MnO}_{2}$ precipitate is doubled to 50 galions.
\end{abstract}




\section{CONTENTS}

$\underline{\text { Page }}$

Introduction

Summary $I$

Discussion 2

Equipment 2

Process Description and Chemistry 2

$\begin{array}{ll}\text { Results } & 4\end{array}$

Test Conditions 4

Removal of Nitrous Acid 6

Centrifugation of $\mathrm{MnO}_{2}$ Precipitate 6

Washing of $\mathrm{MnO}_{2}$ Precipitate 6

$\begin{array}{ll}\text { Plant Processing Rate } & 8\end{array}$

Bibliography 8

\section{LIST OF FIGURES}

\section{Figure}

1 Semiworks Head-End System 3

2 Semiworks Centrifuge 3

3 Removal of Nitrite from Dissolver Solution 7

4 Washing of Centrifuged $\mathrm{MnO}_{2} \quad 7$ 


\section{SEMIWORKS EVALUATION OF THE MANGANESE DIOXIDE HEAD-END STEP IN THE THOREX PROCESS}

\section{INTRODUCTION}

A dilute Thorex process has been developed at the Savannah River Laboratory for separating and purffying ${ }^{23{ }^{3}} \mathrm{U}$ from residual thorlum, fission products, and protactinium. This process w1II be operated in the chemical separations plant that is normally used for processing enriched uranium. A head-end step involving the sorption of ${ }^{233} \mathrm{~Pa}$ and some of the fission products on a manganese dioxide slurry is used to separate the major fraction of protactinlum from the ${ }^{233_{U}}$ and thorium. The slurry is dissolved with sodium nitrite in acid solution, and is then concentrated and stored to permit essentially complete conversion of the ${ }^{233} \mathrm{~Pa}$ to ${ }^{233} \mathrm{U}$ of very high 1 sotopic purity ( $\left.<0.5 \mathrm{ppm}{ }^{232} \mathrm{U}\right)$. Removal of ${ }^{233} \mathrm{~Pa}$ prior to solvent extraction is necessary to prevent excessive radiation damage to the solvent.

Laboratory tests demonstrated adequate sorption of ${ }^{233} \mathrm{~Pa}$ by $\mathrm{MnO}_{2}$ at the levels of radioactivity expected in the plant process solutions. In addition, tests of the Thorex head-end step in plant prototype equipment were necessary to demonstrate that the standard plant procedure(1) for precipitating $\mathrm{MnO}_{2}$ and clarifying the resulting solution is satisfactory, and to define the processing rate of the plant equipment. The results of these tests are presented in this report.

\section{SUMMARY}

Semiworks tests of the head-end step for the $\mathrm{MnO}_{2}$ sorption of ${ }^{233} \mathrm{~Pa}$ from Thorex process feed solutions showed that:

- Approximately 4000 1b thorium per day can be processed through the head-end cycle in the enriched uranium plant.

- Addition of sulfamic acid to the solution prior to prec1pitation of $\mathrm{MnO}_{2}$ is required to decompose nitrous ac1d; otherwise, a fraction of the $\mathrm{MnO}_{2}$ would be dissolved by nitrous acid that is generated radiolytically in the nitric acid solution. One mole of sulfamic acid per mole of nitrous acid is required.

- The supernatant liquid skimmed from the centrifuge must be recycled, because it contains a significant amount of flocculent $\mathrm{MnO}_{2}$. 
- 50 gallons of dilute acld should be used in each of five washes of the $\mathrm{MnO}_{2}$ precipitate - the maximum possible for the size of the bowl. The washes remove thorlum and ${ }^{23} \mathrm{~V}$ which would otherwise contaminate the high purity ${ }^{23{ }^{3}} \mathrm{U}$ that is extracted after decay of ${ }^{233} \mathrm{~Pa}$.

W1th slight changes to include these conditions, the standard Purex plant procedure for precipltating $\mathrm{MnO}_{2}$ and clarlfying the feed solution is satisfactory for the dilute Thorex process.

\section{DISCUSSION}

\section{Equipment}

The semiworks installation, Figure 1, consists of a prototype plant centrifuge and assoclated tankage to simulate plant conditions. The centrifuge, Figure 2, manufactured by the Bird Machine Company, Includes a four-compartment solid bowl that is 40 inches in diameter (60 gallons dynamic volume). The 5-5/8-1nch-hlgh compartments are formed by three perforated baffles that extend 6 inches inward from the wall. The casing of the bowl collects the liquor overflow; the precipitate remains in the compartments. A 40-hp electric motor drives the bowl at speeds up to $1750 \mathrm{rpm}$.

The centrifuge feed jet piping, slurry-removal jet plping, and high pressure spray piping simulate the plant arrangements. A Z-6 plant-rate jet was used for feeding the centrifuge, and a $25-S_{1}$ plant transfer jet was used for removing the slurry from the centrifuge bowl.

A positive displacement pump capable of delivering at $600 \mathrm{psig}$ was used to remove the $\mathrm{MnO}_{2}$ precipitate from the walls of the centrifuge.

\section{Process Description and Chemistry}

In the normal plant procedure for preclpitating $\mathrm{MnO}_{2}$ and clarifying Purex feed, approximately 60-pound-batches of manganese dioxide precipltate are formed by adding manganous nitrate solution to the dissolver solution at $70^{\circ} \mathrm{C}$, and then adding a stoichiometrically deficlent amount of potassium permanganate solution at a slow rate. The reaction between the manganous nitrate and potassium permanganate can be represented as follows:

$$
3 \mathrm{Mn}\left(\mathrm{NO}_{3}\right)_{2}+2 \mathrm{KMnO}_{4}+2 \mathrm{H}_{2} \mathrm{O} \rightarrow 5 \mathrm{MnO}_{2}+2 \mathrm{KNO}_{3}+4 \mathrm{HNO}_{3}
$$




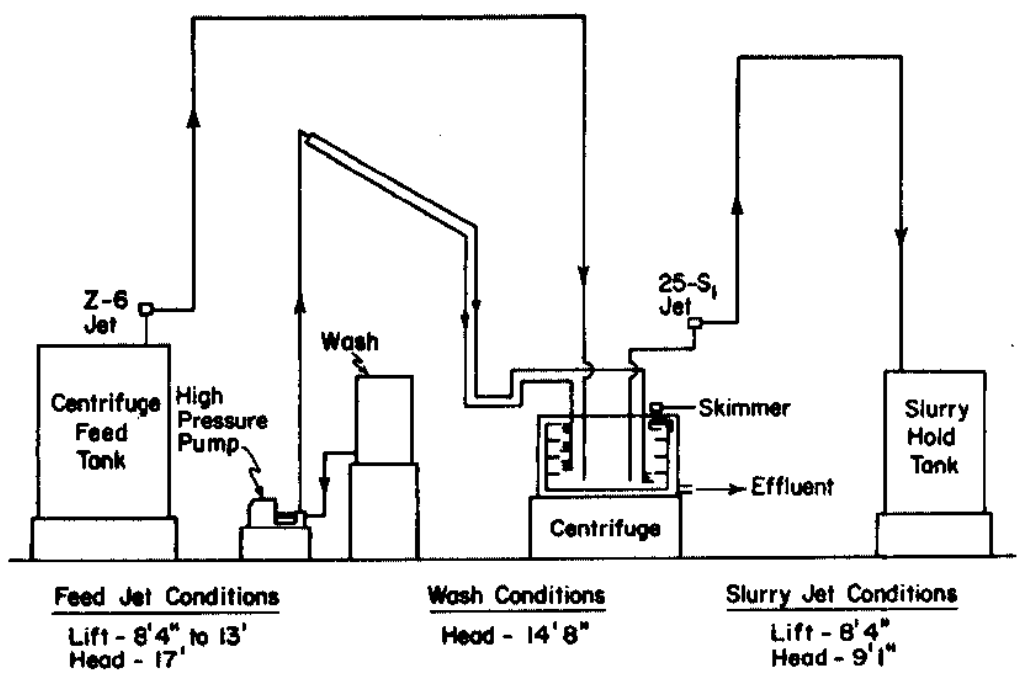

FIG. I SEMIWORKS HEAD -END SYSTEM

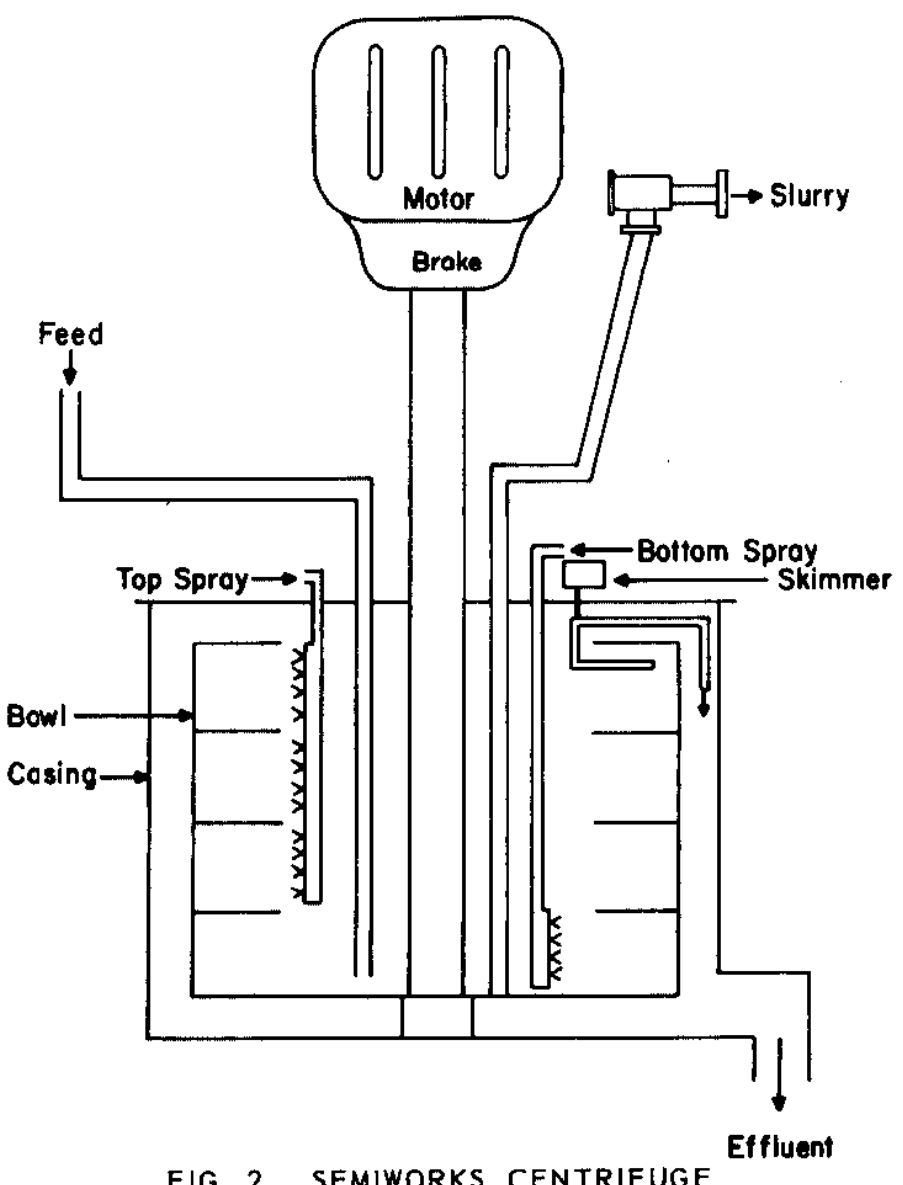

FIG. 2 SEMIWORKS CENTRIFUGE 
The quantity of permanganate is sufflclent to oxidize only about $85 \%$ of the manganous ion in order to avold a strongly oxidizing environment that releases ruthenlum. The resulting manganese dioxide slurry, which constitutes one full load of the centrifuge, is digested at $70^{\circ} \mathrm{C}$, cooled to $40^{\circ} \mathrm{C}$, and transferred to the centrifuge at a maximum rate of $12 \mathrm{gal} / \mathrm{min}$ with a steam jet pump. The final volume of supernate retained in the centrifuge is reduced by decreasing the centrifuge speed from 1740 to $870 \mathrm{rpm}$ and skimming the liquid to the effluent catch tank. The clarifled solution is then ready for solvent extraction.

The $\mathrm{MnO}_{2}$ preclpitate is subjected to flve successive washes as follows:

The cake is slurried of $f$ the bowl wall by spraying 20 to 25 gallons of $0.1 \mathrm{M} \mathrm{HNO}_{3}$ into the four horizontal compartments of the bowl at approximately $600 \mathrm{psig}$. The slurry is agitated five times by alternately rotating and suddenly stopping the bowl. After recentrifuging the $\mathrm{MnO}_{2}$, each wash solution is skimmed from the bowl. After the final wash, the cake is slurried from the bowl in four flushes and jetted to the slurry hold tank.

The above procedure was followed during the plant-scale tests of the procedure for $\mathrm{MnO}_{2}$ sorption of ${ }^{233} \mathrm{~Pa}$ from dissolved thoria contalning ${ }^{233} \mathrm{U}$. In these tests unirradiated thorla was used, no ${ }^{233} \mathrm{~Pa}$ was present, and ${ }^{238} \mathrm{U}$ was substituted for ${ }^{233} \mathrm{U}$.

\section{RESULTS}

\section{Test Conditions}

Laboratory data showed that, for effective sorption of ${ }^{233} \mathrm{~Pa}$ by $\mathrm{MnO}_{2}$, the concentration of the dissolver solution should not exceed $0.4 \mathrm{M} \mathrm{Th}-0.7 \mathrm{M} \mathrm{Al}-0.8 \mathrm{M} \mathrm{HNO}_{3}$. Two semiworks tests were made with plant-scale equipment and simulated dissolver solution at the maximum thorium and aluminum concentrations, but with varied acid concentrations. A small amount of mercuric nitrate was also used in the second test because the aluminum cladding of the thoria target elements is dissolved with mercury as a catalyst. The data from the two tests are summarlzed in the following table: 
$\mathrm{MrO}_{2}$ Preparation and Centrifugation Tests

Simulated plant agitation during preclpitation

Test I Test II

\begin{tabular}{|c|c|c|}
\hline $\operatorname{Th}\left(\mathrm{NO}_{3}\right)_{4}, \mathrm{M}$ & 0.37 & 0.41 \\
\hline $\mathrm{HNO}_{3}, \mathrm{M}$ & 0.39 & 0.77 \\
\hline $\mathrm{A} I\left(\mathrm{NO}_{3}\right)_{3}, \mathrm{M}$ & 0.66 & 0.81 \\
\hline $\mathrm{U}, \mathrm{g} / \mathrm{liter}$ & 0.21 & 0.85 \\
\hline $\mathrm{NO}_{2}^{-}, \mathrm{M}$ & 0.0074 & 0.0087 \\
\hline $\mathrm{Hg}\left(\mathrm{NO}_{3}\right)_{2}, \mathrm{M}$ & - & 0.0025 \\
\hline Specific gravity & 1.2805 & 1.3162 \\
\hline $\begin{array}{l}\mathrm{NO}_{2}^{-} \text {after addition of } 1 \text { mole sulfamic acid per mole } \\
\mathrm{NO}_{2}^{-}, \mathrm{M}\end{array}$ & $10^{-6}$ & $10^{-6}$ \\
\hline $\mathrm{MnO}_{2}$ formed, Ib & 62 & 58 \\
\hline $\mathrm{MnO}_{2} / \mathrm{Th}$, (a) mole ratio & 0.086 & 0.073 \\
\hline Feed rate to plant prototype centrifuge, gpm & $11-15$ & 13 \\
\hline $\begin{array}{l}\mathrm{MnO}_{2} \text { in first } 100 \text { galions of centrifuge effluent, (b) } \\
\% \text { of total }\end{array}$ & 0.12 & 0.21 \\
\hline $\mathrm{MnO}_{2}$ in remainder of centrifuge effluent, $\%$ of total & 0 & 0 \\
\hline $\mathrm{MnO}_{2}$ in skimmed, supernatant liquid, \% of total & $0.1 I$ & 0.22 \\
\hline $\mathrm{MnO}_{2}$ in washes, (b) \% of total & 1.9 & 1.8 \\
\hline Volume of $\mathrm{MnO}_{2}$ in centrifuge, (c) gaI & 33 & 26 \\
\hline $\mathrm{MnO}_{2}$ removed from centrifuge, (d) $\%$ of total & 93.0 & $97 \cdot 7$ \\
\hline Dilute acid in each of five washes, gal & 25 & 50 \\
\hline Product washed from precipitate, of total in feed & & \\
\hline Uranium & 1.3 & 1.3 \\
\hline Thorium & 0.9 & 1.4 \\
\hline $\begin{array}{l}\text { Residual product in washed precipltate, } \% \text { of total } \\
\text { in feed. }\end{array}$ & & \\
\hline $\operatorname{Urantum}(e)$ & & 0.03 \\
\hline Thortum & 0.13 & 0.007 \\
\hline
\end{tabular}

(a) Normal ratio in plant $=0.053$ (60 $1 \mathrm{~b} \mathrm{MnO}_{2}$ per 4000 gal solution). Semlworks tank limited to 2700 gal.

(b) Normally recycled to later batch.

(c) This volume reduces to about 10 gal durlng the ac1d washes.

(d) Material balance within accuracy of $\mathrm{MnO}_{2}$ analysis.

(e) This uranium will be extracted after the ${ }^{233} \mathrm{~Pa}$ decays to ${ }^{233} \mathrm{U}$. 


\section{Removal of Nitrous Acid}

Any nitrous acid that is generated radiolytically in the dissolver solution will interfere with ${ }^{233} \mathrm{~Pa}$ recovery either by reacting with the $\mathrm{KMnO}_{4}$ or by dissolving the $\mathrm{MnO}_{2}$ precipitate after formation. Data for the removal of nitrous acld from the dissolver solution are summarized in Flgure 3. The concentration of nitrous acid in the dissolver was not changed by heating to $70^{\circ} \mathrm{C}$ during normal plant agitation. Sparging with air at $10 \mathrm{scfm}$ removed the nitrous acid, but only at a very slow rate that was not improved by increasing the sparge to 14.5 scfm. Addition of sulfamic acid completely destroyed the nitrous acld; at least 1 mole of sulfamic acid per mole of $\mathrm{NO}_{2}^{-}$is needed to ensure removal of the nitrous acid.

\section{Centrifugation of $\mathrm{MnO}_{2}$ Precipitate}

The $\mathrm{MnO}_{2}$ prepared at the semiworks was very similar to that prepared in the laboratory. $\mathrm{MnO}_{2}$ formed in the presence of aluminum and thorium is more flocculent than that formed when the analogous procedure is used in the Purex process. Although the higher aclitty of the second feed solution apparently decreased the bulk volume of the 60-1b precipitate from 33 to 26 gallons (Purex volume ranges from 13 to 20 gallons), little difference was seen in the centrifuging characteristics. The volume of the precipltate reduces to 10 galions during washing, the same volume as in the Purex process. The slurry was fed to the centrifuge at 11 to $15 \mathrm{gpm}$ with no breakthrough to the effluent except in the first 100 gallons, which is recycled. However, a significant amount of flocculent $\mathrm{MnO}_{2}$ is unavoldably skimmed with the final supernatant solution, which must be recycled. The wash solution also contained a significant amount of precipitate and was recycled.

\section{Woshing of $\mathrm{MnO}_{2}$ Precipitate}

About 1 to $2 \%$ of the uranium and thorlum in the dissolver solution remained in the centrifuge with the precipitate after the final supernatant solution was removed by skimming. The volume of $0.1 \mathrm{M} \mathrm{HNO}_{3}$ for each wash was doubled (to 50 gallons) to remove this residual uranium and thorium with the normal five washes, as shown in Figure 4. With this procedure, ${ }^{233} \mathrm{U}$ essentially free from ${ }^{232} \mathrm{U}$ can be obtalned from the $\mathrm{MnO}_{2}$ after the ${ }^{233} \mathrm{~Pa}$ has decayed. The increase in volume of each wash (rather than in the number of washes) has no marked effect on the time cycle. A wash volume greater than 50 gallons added to the 10 gallons of $\mathrm{MnO}_{2}$ would overflow the bowl, which has a dynamic holdup of 60 gallons. 


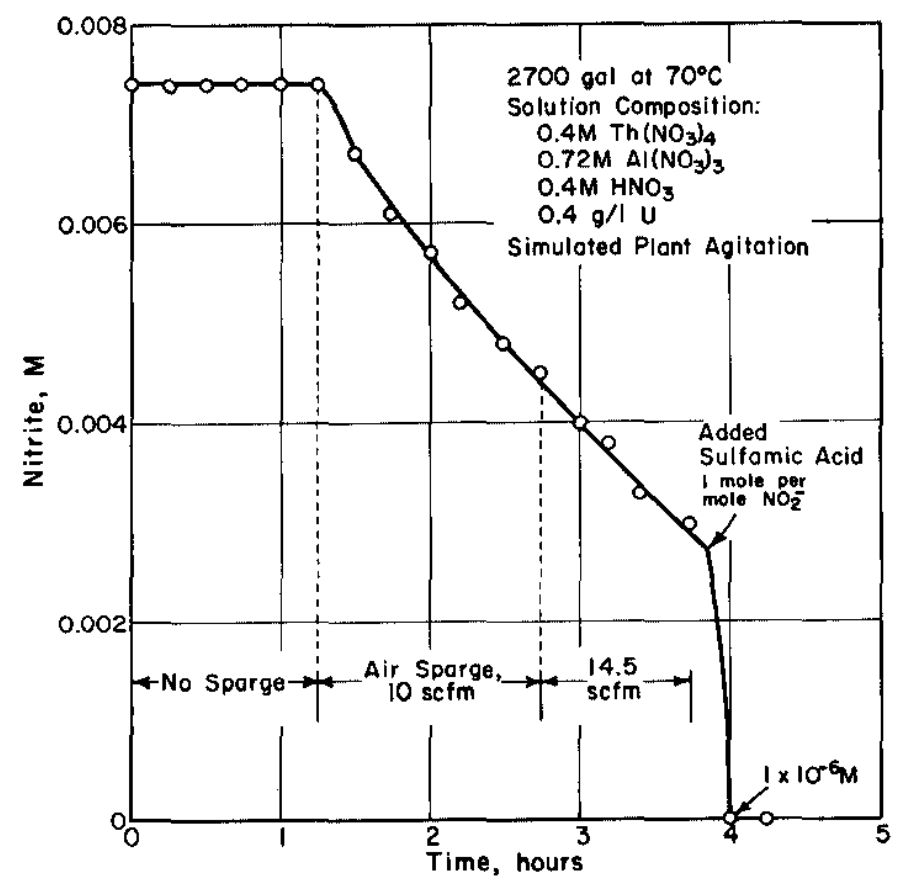

FIG. 3 REMOVAL OF NITRITE FROM DISSOLVER SOLUTION

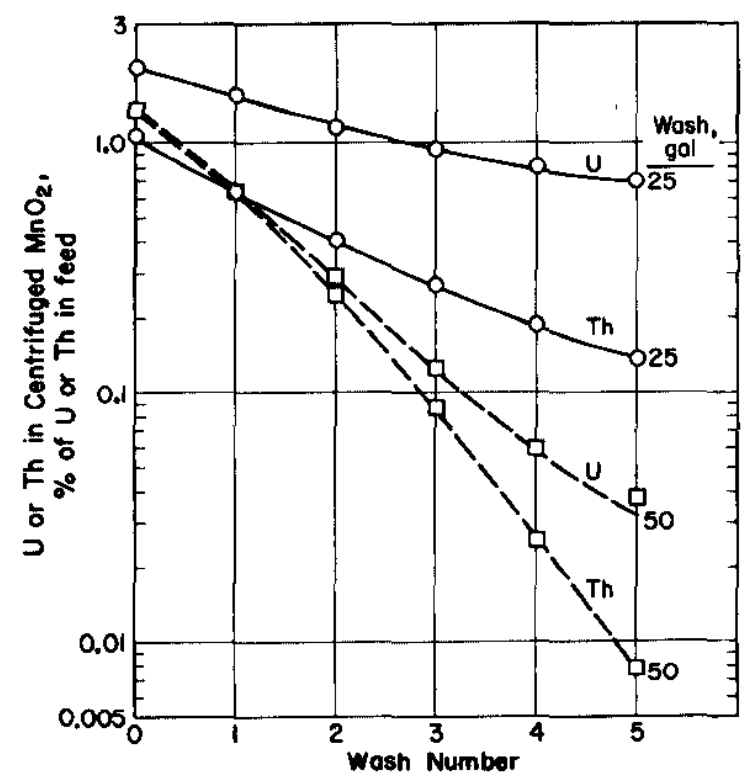

FIG. 4 WASHING OF CENTRIFUGED $\mathrm{MnO}_{2}$ 


\section{Plant Processing Rate}

The plant head-end cycle for the dilute Thorex process will require a total of 18 hours to process $3000 \mathrm{lb}$ of thorlum. Therefore, the plant head-end processing rate w1ll be $\sim 4000 \mathrm{lb} \mathrm{Th} / \mathrm{day}$. The detalled schedule is shown in the following table.

\section{Head-End Time Cycle}

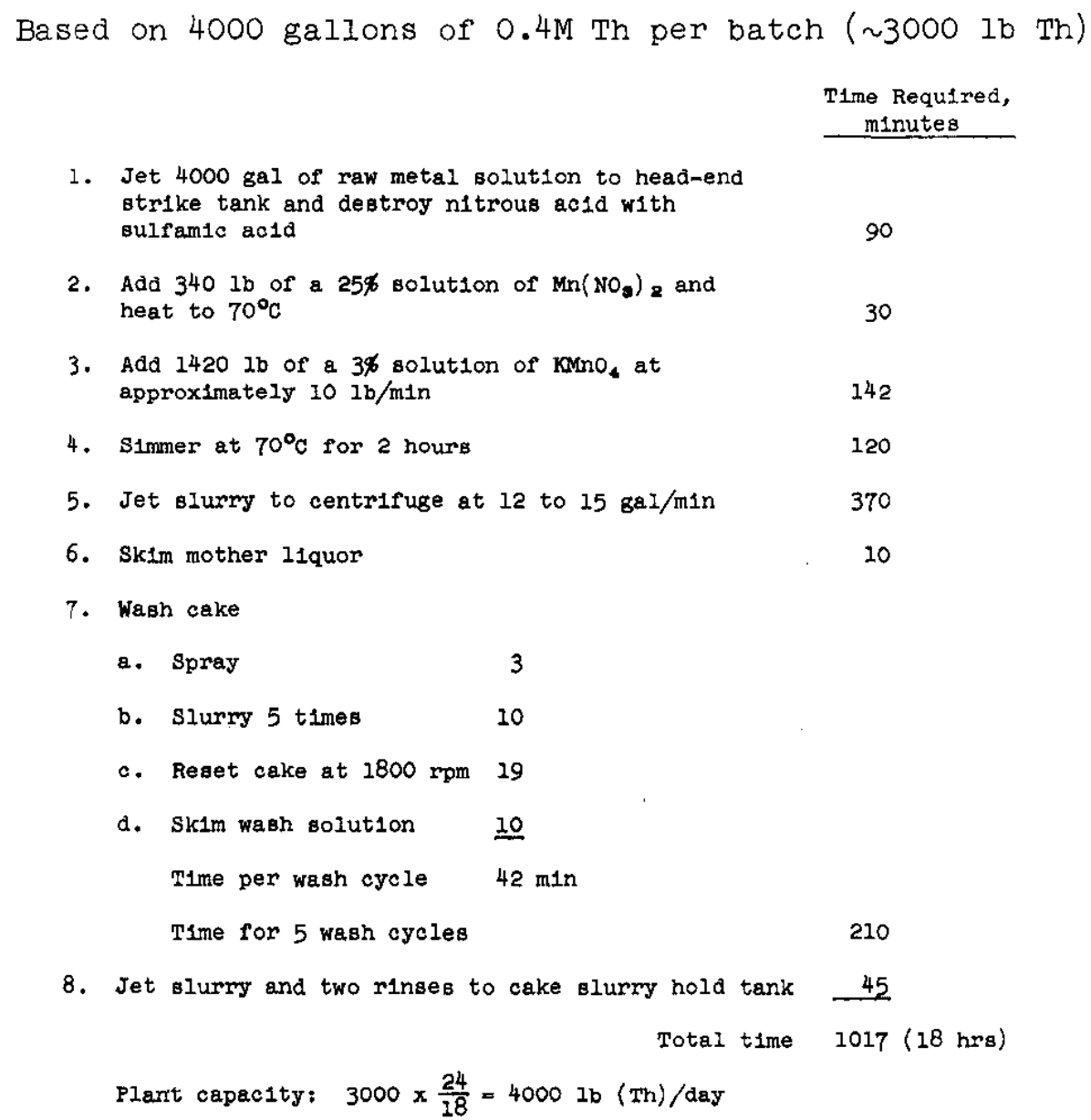

\section{BIBLIOGRAPHY}

1. D. G. Karraker and S. G. Parker. Evaluation of the Reverse Strike Head-End Procedure. USAEC Research and Development Report, DP-259. E. I. du Pont de Nemours and Co., Savannah River Laboratory, Aiken, S. C. (1957). 